\title{
IMPROVING THE PROPERTIES OF CLAY SOIL BY USING LATERITE SOIL FOR PRODUCTION OF BRICKS
}

\author{
Anteneh GEREMEW ${ }^{1, *}$ and Yibas MAMUYE ${ }^{1}$ \\ ${ }^{1}$ Department of Civil Engineering, Jimma University, Jimma, Ethiopia. \\ corresponding author: antjiren@gmail.com.
}

\begin{abstract}
Nowadays, the utilization of locally accessible materials is a crucial stage for sustainable, economical building material on the earth's surface. Within them, brick is one of the commonly used construction materials around Jimma town due to the availability of clayed soil. Nevertheless, brick produced by small micros unskilled enterprises rather than by traditional methods, its quantity was small, and its quality was unsatisfactory because it can easily break, and it has high water-absorbing conduct. The purpose of the investigation was to improve the properties of clayed soil properties by using laterite soil for the manufacturing of bricks for masonry units. In order to achieve this, research used non-probability sampling techniques to collect samples in Jimma area. Then, the collected samples prepared for different laboratory tests and by partially replacing literate soil by $5 \%, 10 \%, 15 \%$ and $20 \%$ on a clayed soil in order to get optimum property by different mix ratio for different laboratory tests results indicated showed that the lightweight bricks could be made from the approach of this study without any deterioration in the quality of bricks.

Additionally, the compressive strength of the blocks optimum at $15 \%$ lateritic soil replaces in clayed soil contents. The optimum firing temperature furnace at a duration burning of brick was at $1000^{\circ} \mathrm{C}$ for $5 \mathrm{hrs}$. It has shown that bricks prepared of clay-laterite earth capable of high resisting capacity rather than for beauty.
\end{abstract}

\author{
Keywords: \\ Laterite soil; \\ Brick; \\ Clayed soil; \\ Compressive strength; \\ Water absorption.
}

\section{Introduction}

Ethiopia, one of the fast economic growth in East-Africa [1]. Due to urbanization, the number of populations living in towns becoming increases day to day; so that for sustainable living standards in a town constructing a house un-questionable for human beings, although the cost of a unit black of plain concrete highly increases [2]. There was a small number of micro-enterprises production clay brick with a traditional way without controlling the quality; only by looking at a brick face beauty, but there was a large deposit of clayed soil and literate soil in the Jimma area [3]. Laterite earth material was considered to be one of the oldest and commonly used building materials. It was considered to be one of the essential construction materials on the earth's surface was widespread [4]. Unfortunately, laterite earth construction in developed countries is diminishing with the abrupt changes in construction materials and methods [5]. Good quality bricks can be manufactured using lateritic soil provided that accepted clay material has added. The use of plastic clayed alone in the production of brick may not be suitable due to shrinkage and warping effect during the drying process [6]. Partially substituting clay earth with disbursed unwanted shea has upgraded the scientific enactment of black of the earth in decrease the mass, improved in performance satisfies specification [7].

Appropriateness of the application of natural flavors in brick earth to be established was upgraded competence and continuing. Therefore it decreases ecological effect [8]. Burring of a unit of earth brick exhaustive a tremendous amount of power utilized approximately 24 million tons per annual; this is one of the major causes of the environmental defect [9]. A Block earth material has 
numerous practices on construction industry resources [10].

According to [6], the application of lateritic brick added clay started around 8000 B.C. in Mesopotamia, the construction of houses, dams, and roads. Most of the builders and construction peoples value most of the soil. Due to its durability and cost-effectiveness, it can also be considered as an excellent sustainable material in the construction and recycling process, for it can minimize pollution and has low carbon emission during the application [11]. The application of laterite earth in building construction almost exists anywhere in the world, especially in third world countries. In a country like Kano, Kaduna, and other cities in Northern Nigeria, the use of this material is beneficial. However, it has noted that laterite earth is also applied in developing countries [6, 12]. In many countries, in Asia and Africa, more than two billion peoples are using in building or house construction using lateritic earth and clay products. The application of these materials has earned many advantages by determining its quality, identifying its characteristics, and its application in construction

Additionally, it improves the quality of lateritic earth, additives, and removes one of its contents is also an option [13]. The reduction of energy requirement in the production of a brick using lateritic soil is an advantage. It will be produced using $5 \mathrm{kWh} / \mathrm{m}^{3}$ compared to fired brick and concrete blocks, which consume $1000 \mathrm{kWh} / \mathrm{m}^{3}$ and $450 \mathrm{kWh} / \mathrm{m}^{3}$, respectively. Additionally, lateritic soil structure is easily recyclable without polluting the environment [14]. Due to its availability or existence in any part of the world, the application of its uses in environment building construction is very crucial. It is available in many different compositions, which needs further investigation when added to other materials such as clay to produced sustainable structure $[6,15,16]$.

Brick extensively adopted building material around Jimma town. Unlike other cities outside of Jimma, they used most implemented for modern households, pale, and ancient houses have intensively built by block partition and pillars. Particularly ancient structures brick pillars and partitions were precise exciting, which occur today without major failure and attending still current time. Nevertheless, the research conducted shown by [17] shows that the brick produced nearby the Jimma area where below standard specifications. Besides, small micros enterprises are producing clay brick for low-cost houses these days in small amounts and with unsatisfactory quality, which can easily break and with high water absorbing behavior. It has also known that many people are not using these days for load-bearing purposes but instead for aesthetic and fence purposes only. This study has improved the physical properties of the brick by mixing clayed soil with laterite soil. So based on this, it encourages the use of locally available material for the production of brick for affordable and lowcost construction of houses. This study was an excellent opportunity for job creation for the society living around Jimma town.

\section{Materials required and methods}

\subsection{Materials required}

In order to succeed the objective, purposive sampling techniques have implemented; Lateritic soil sampled around Jimma town and a clayed soil having high plasticity collected at a depth of $0.5 \mathrm{~m}$ in order to protect other organic material and also clay samples were collected by using engineering judgment, by observing color texture, and by its index property.

\subsection{Preparation of brick}

The clayed soil has utilized for this particular research was selected with high plastic contents. In order to improve the property of the clayed soil, different percentages of laterite soil $5 \%, 10 \%$, $15 \%$, and $20 \%$ (through mass) been used, and finally, uniform mixing carried until the same color obtained. Atterberg limit tests performed on different percentages of lateritic soil added to the clayed soil. Water added in the mixes, prepared until it gives consistency, workable, and suitable for different percentage of brick preparation; and proper mixing done in the preparation of bricks.

The following procedure used during the production of clay-lateritic brick units:

1. The collected samples, lateritic and clayed soil, allowed for drying separately.

2. By breaking the samples and grinding in small particles until the required sieve size pass.

3. Preparing mix design (according to the percentage) required and separately by adding the necessary quantity of water for different mix until the favorable for workability, finally mix stored in a cold room for at least two days until the uniform distribution of water attained in the mixture. 
4. Before molding starts, the mold dipped in water in order to prevent sticking and poured the mix in the mold by thrown forcedly by hand until it attains a roughly shaped. The thin wire cable removed the excess on the top of the mold. Immediately, the molded brick then removed from the mold and dried in the sun for a week, and finally, the bricks were furnace oven-dried at $1000{ }^{\circ} \mathrm{C}$ for 5 hours.

\subsection{Methods and standard testing procedure}

Table 1: Summary of test method.

\begin{tabular}{|c|c|}
\hline Type of test & Test method/ Designations \\
\hline MOISTURE CONTENT & AASHTO T - 265 \\
\hline SIEVE ANALYSIS & ASTM -D422-63 \\
\hline ATTERBERG LIMITS & ASTM -D4318-98 \\
\hline SOIL GROUPING & ASTM -D2487-98 \\
\hline SPECIFIC GRAVITY & ASTM -D854-83 \\
\hline PROCTOR TEST & ASTM -D698-98 \\
\hline COMPRESSIVE TEST & IS 3495 (PART I-III) and IS 3346:1980 \\
\hline PREPARATION OF SAMPLES & IS 1077:1992 \\
\hline EFFLORESCENCE & IS 3495 (part III) - 1992 \\
\hline
\end{tabular}

\section{Result and discussion}

\subsection{Engineering properties of lateritic soil and clay soil}

\subsubsection{Identification of engineering properties of lateritic soils}

In order to control the quality of the materials, laboratory tests were carried out based on the standard specification. The experiments elaborate to classify the belongings lateritic earth, such as its physical and mechanical possessions.

Table 2: Geotechnical properties of lateritic soil.

\begin{tabular}{|c|c|c|}
\hline $\mathrm{S} / \mathrm{N}$ & Attribute & Empirical Standards \\
\hline \multirow{4}{*}{1} & \multicolumn{2}{|l|}{ Catalog } \\
\hline & AASHTO & A-2-7 \\
\hline & USCS cluster & SC \\
\hline & USCS cluster & poorly -graded sands \\
\hline 2 & Specific gravity & 2.37 \\
\hline \multirow{3}{*}{3} & Sieve analysis & \\
\hline & Sand content $\%$ ( 4.75 to $0.075 \mathrm{~mm}$ ) & 62.4 \\
\hline & Silt and clay content $\%$ (under $0.075 \mathrm{~mm}$. ) & 37.6 \\
\hline \multirow{4}{*}{4} & Atterberg's limits: \% & \\
\hline & Liquid limit & 78.54 \\
\hline & Plastic limit & 41.19 \\
\hline & Plasticity index & 37.35 \\
\hline \multirow{3}{*}{5} & \multicolumn{2}{|c|}{ Proctor test } \\
\hline & Optimum moisture content (OMC), \% & 41.56 \\
\hline & Maximum dry density $\left(\mathrm{g} / \mathrm{cm}^{3}\right)$ & 1.31 \\
\hline 6 & Red literate soil & By visual inspection \\
\hline
\end{tabular}




\subsubsection{Engineering belongings of clayed soil}

The experiments elaborate to classify the possessions of the clayed earth, such as their physical and mechanical possessions. Therefore investigations carried out on the unprocessed clay earth contain sieve analysis, Atterberg limit test, compaction test, California bearing ratio, and specific gravity.

Table 3: Geotechnical properties of clayed earth.

\begin{tabular}{|c|c|c|}
\hline $\mathbf{S} / \mathbf{N}$ & Attribute & Empirical standards \\
\hline \multirow{4}{*}{1} & Catalog & \\
\hline & AASHTO & $A-2-5$ \\
\hline & USCS cluster & $\mathrm{CH}$ \\
\hline & USCS cluster & Soft Soil \\
\hline 2 & Specific gravity & 2.485 \\
\hline \multirow{4}{*}{3} & Sieve analysis & \\
\hline & Gravel content $\%$ (20 to $4.75 \mathrm{~mm}$.) & 0.533 \\
\hline & Sand content \% (4.75 to $0.075 \mathrm{~mm})$ & 4.952 \\
\hline & Silt and clay content $\%$ (below $0.075 \mathrm{~mm}$.) & 94.515 \\
\hline \multirow{4}{*}{4} & Atterberg's limits: \% & \\
\hline & Liquid limit & 87.42 \\
\hline & Plastic limit & 31.85 \\
\hline & Plasticity index & 55.57 \\
\hline \multirow{3}{*}{5} & Proctor test & \\
\hline & Optimum moisture content (OMC), \% & 34.54 \\
\hline & Maximum dry density ( $\mathrm{g} / \mathrm{cm} 3$ ) & 1.235 \\
\hline 6. & Greyish clayed soil & By visual inspection \\
\hline
\end{tabular}

\subsection{Casting of bricks}

\subsubsection{Preparation of mixed clay-lateritic soil}

As control of the test, a clay brick alone was prepared accordingly and shaped based on the size of the box and burn in a furnace oven. Additionally to this, unlike proportion of laterite earth added $5 \%, 10 \%, 15 \%$, and $20 \%$. The blends were set with the pre-determined optimum moisture content values. The size of the box of bricks to be cast dimension of $230 \times 110 \times 70 \mathrm{~mm}$ non-modular bricks. It is evident as per IS 1077:1992. The arranged combination forced into the mold, and subsequently removing the mold, retained for sun drying. The prepared sample of bricks was allowed to dry until it reduces the moisture content. Exposing to ventilation to sun drying period approximately a week and finally transferring the samples to the furnace oven and burn at a temperature of $1000^{\circ} \mathrm{C}$ for 5 hours. Sample of bricks taken out from the furnace oven and allow to cool; and then the laboratory testing followed after 21 days of curing as per IS code.

\subsubsection{Test methods}

The bricks were tested as per IS code for finding the physical properties. The burned bricks cured for 21 days, and only after that, testing can be started. Compressive strength, water absorption, efflorescence, and thermal conductivity are the tests conducted on the bricks. The experiments continuously conducted as per IS 3495 (PART I-III) and as per IS 3346:1980. 


\subsection{Discussion of test result}

Clay bricks made with laterite soil tested for analyzing the physical properties of bricks such as the Atterberg limit test, compressive strength, water absorption, efflorescence, and thermal conductivity.

\subsubsection{Atterberg limit test and workable mixing water contents}

The results of Atterberg limit tests and workable mixing water contents shown in Table 4 and Fig.1 based on standard specification [19, 20]. Both liquid and plastic limits have decreased, with increasing of the percentage of laterite content. However, also the workable mixing water content decreases with increase percentage laterite. Shows in Table 4, a summary of the results of Atterberg's limits.

Plastic Index = Liquid limit - Plastic limit .

Table 4: Effect of laterite soil on Atterberg limits.

\begin{tabular}{|c|c|c|c|c|}
\hline Laterite soil content (\%) & Liquid limit (\%) & Plastic limit (\%) & Plastic index (\%) & Mixing water contents (\%) \\
\hline 0 & 87.42 & 31.85 & 55.57 & 38.98 \\
\hline 5 & 83.54 & 30.11 & 53.43 & 35.49 \\
\hline 10 & 76.25 & 27.47 & 48.78 & 33.47 \\
\hline 15 & 69.05 & 22.61 & 46.44 & 31.19 \\
\hline 20 & 53.77 & 18.87 & 34.9 & 30.09 \\
\hline
\end{tabular}

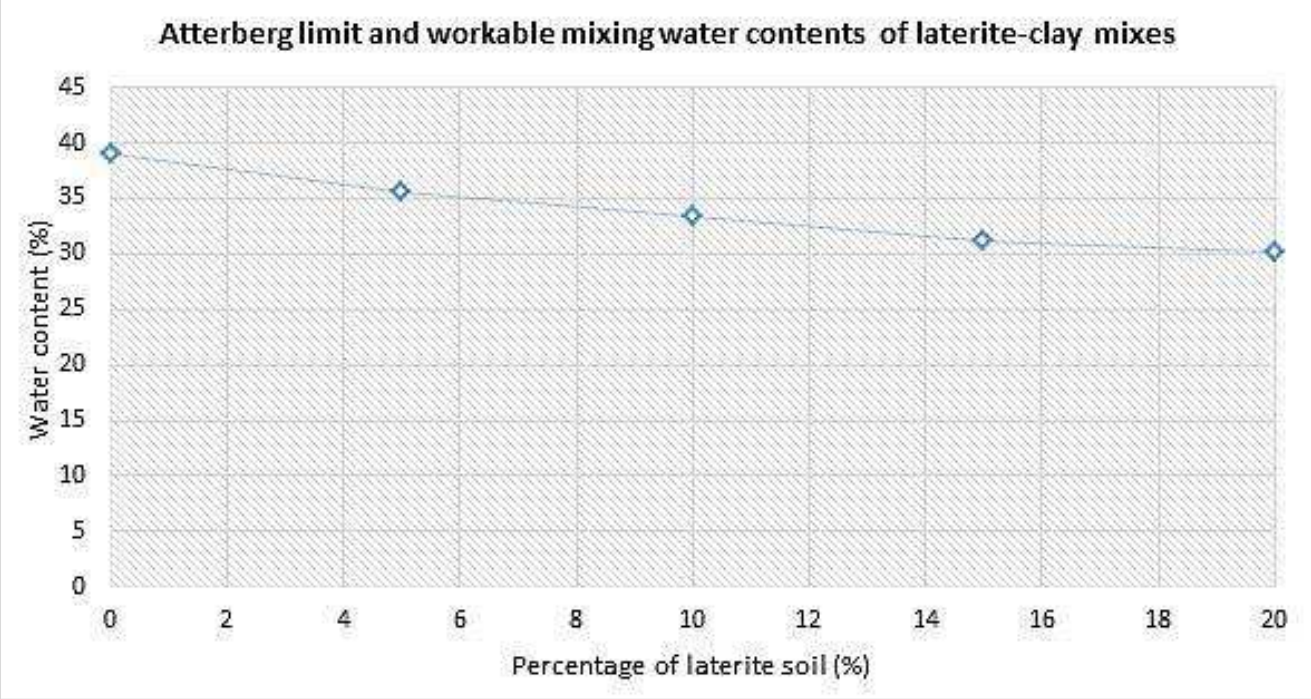

Fig.1: Water contents verses percentage of laterite in clay soil.

\subsubsection{Linear shrinkage and density}

The summary of the results of linear shrinkage, and dry and firing densities are shown in Table 5 , the shrinkage decreases with an increase of the laterite soil contents but decreases in dry density.

Table 5: Effect of laterite soil on linear shrinkage, dry and after furnace densities of clay-laterite.

\begin{tabular}{|c|c|c|c|}
\hline Laterite soil content (\%) & Linear shrinkage (\%) & Dry density $\left(\mathbf{k g} / \mathbf{m}^{\mathbf{3}}\right)$ & After furnace oven $\left.\mathbf{( k g} / \mathbf{m}^{\mathbf{3}}\right)$ \\
\hline 0 & 11.63 & 1820 & 1753 \\
\hline 5 & 10.16 & 1756 & 1654 \\
\hline 10 & 9.25 & 1611 & 1488 \\
\hline 15 & 8.85 & 1523 & 1376 \\
\hline 20 & 6.11 & 1402 & 1224 \\
\hline
\end{tabular}




\subsubsection{Compressive strength of clay bricks with laterite soil}

The compressive strength test results of produced clay-laterite bricks made with different percentages of laterite soil with $0 \%, 5 \%, 10 \%, 15 \%$, and $20 \%$ are shown below in Table 6, Fig. 2 .

Average stress $(\boldsymbol{\delta})=\frac{\text { maximum load }(\mathrm{KN})}{\text { Average area of bed face }\left(\mathrm{mm}^{2}\right)}$.

Table 6: Compressive strength values of clay-laterite bricks with laterite soil.

\begin{tabular}{|c|c|c|}
\hline Laterite soil content (\%) & Compressive strength or stress, $\sigma(\mathrm{MPa})$ & Specification \\
\hline 0 & 10.76 & \multirow{5}{*}{$\begin{array}{c}\text { Compressive strength } \\
\text { not less than } 10 \mathrm{~N} / \mathrm{mm}^{2} \\
\text { for class designation } \\
100[18]\end{array}$} \\
\hline 5 & 10.96 & \\
\hline 10 & 11.19 & \\
\hline 15 & 11.37 & \\
\hline 20 & 11.29 & \\
\hline
\end{tabular}

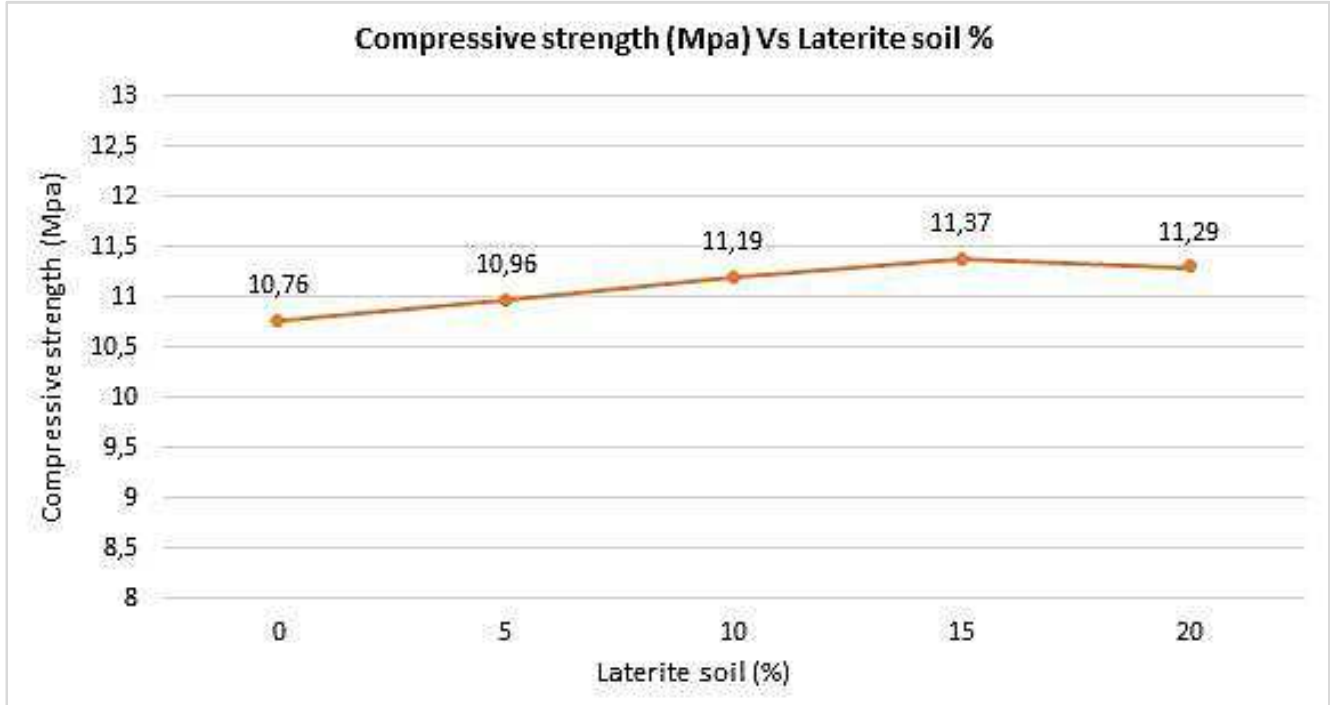

Fig. 2: Variation of compressive strength results of clayed bricks with laterite soil.

On the porosity and density of the bricks, the compressive strength is depending mainly on it. The results of clay bricks with laterite soil show a compressive strength greater than $10 \mathrm{MPa}$, which belongs to class designation 100 as per Indian standard specification. All the modified bricks showed higher strength than control bricks.

\subsubsection{Water absorption}

As the percentage of laterite soil increases, water absorption decrease, Table 7 and Fig. 3.

Table 7: Water absorption test result of produced bricks with clay-laterite.

\begin{tabular}{|c|c|}
\hline Laterite soil content (\%) & Water absorption (\%) \\
\hline 0 & 16.25 \\
\hline 5 & 15.54 \\
\hline 10 & 14.48 \\
\hline 15 & 13.04 \\
\hline 20 & 11.55 \\
\hline
\end{tabular}




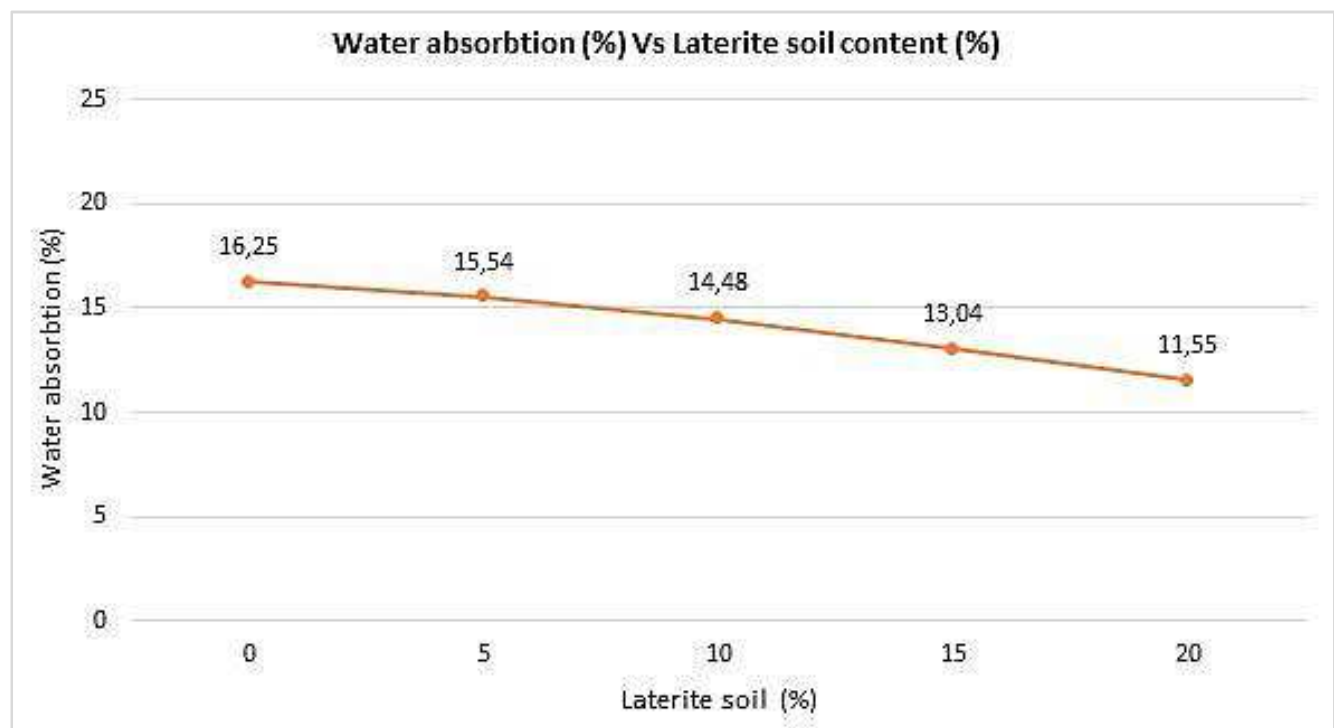

Fig. 3: Variation of water absorption of clay bricks with laterite soil.

Based on the experiment achieved in the laboratory for the manufactured bricks made with laterite soil have similar properties obtained as the control bricks. Laterite soil - clay brick shows a lesser water absorption rate as compared to the standard specification of the class.

\subsubsection{Efflorescence}

Efflorescence was determined to find the alkaline salt content in bricks. The test conducted as per IS 3495 (part III) - 1992. In this experimental work, no noticeable deposit has observed on the majority of samples, but there is a very thin deposit of salts observed on certain brick parts of samples.

\section{Conclusion}

The laterite earth soils were classified based on the ASSHTO classification system as the A-2-7 category with poorly graded gravel and based on the USCS as SC soil groups. The compaction test for the laterite soils yielded MDD and OMC with $1.31 \mathrm{~g} / \mathrm{cc}$ and $41.56 \%$ respectively. The clay soils were classified based on the ASSHTO classification system as the A-2-5 category with high plastic clay and based on the USCS as $\mathrm{CH}$ soil groups. The compaction test for the clay soils yielded MDD and OMC which $1.235 \mathrm{~g} / \mathrm{cc}$ and $34.54 \%$ respectively.

The density of brick decreases with an increase in laterite contents. Lightweight bricks can thus produced without any deterioration in the quality of the bricks. Modified clay bricks showed an increase in compressive strength up to a particular percentage; beyond that point, compressive strength decreases. This is due to the less bonding between clay-laterite and lesser density of the modified bricks. Water absorption decreases with an increasing percentage of addition laterite soil. This is due to the coarser soil particles in bricks; this results in less water absorption. Samples of bricks have minor efflorescence content observed on the face of brick. It shows less amount of the alkaline salt content in those bricks.

Bricks prepared of clay-lateritic combinations also utilized for high resisting capacity for simple structure except for underground structures. In order to recognize the long term effects of the claylaterite block on the toughness of bricks and to examine the chemical composition of clay-laterite soil materials, more research needed.

\section{References}

[1] UNDP, ETHIOPIA: Country Economic Brief, UNDP Ethiop. Policy Advis. Unit, no. 1, 2014,.pp. 115.

[2] Asian Development Bank, Urbanization, and Sustainability in Asia: Case Studies of Good Practice, Adb, 2006, p. 516. 
[3] UNIDO, OCCASION, This publication has been made available to the public on the occasion of the 50. 2007.

[4] KASTHURBA, A.K. - SANTHANAM, M. - MATHEWS, M. S.: Investigation of laterite stones for building purpose from Malabar region, Kerala state, SW India - Part 1: Field studies and profile characterization, Vol. 21, 2007, pp. 73-82.

[5] RAHMAN, M.A.: The potentials of lateritic soil-Clay and clay-sand mixes in the manufacturing of bricks for masonry units. Build. Environ., Vol. 22, No. 4, 1987, pp. 325-330.

[6] MUDI, M. - ALIYU, A.A.: An Examination of the Properties of Literate and Clay as Construction Materials for Sustainable Buildings in Kano and Kaduna Metropolis. Nigeria, July 2012, pp. 1-7.

[7] ADAZABRA, A.N. - VIRUTHAGIRI, G. - SHANMUGAM, N.: An assessment on the sustainable production of construction clay bricks with spent shea waste as renewable ecological material. Vol. 1, No. 2, 2018.

[8] LOZANO-MIRALLES, J.A. - HERMOSO-ORZÁEZ, M.J. - MARTÍNEZ-GARCÍA, C. - ROJAS-SOLA, J.I.: Comparative study on the environmental impact of traditional clay bricks mixed with organic waste using life cycle analysis, Sustain., Vol. 10, No. 8, 2018.

[9] MARY, M.L. - PETER, C. - MOHAN, K. - GREENS, S.- GEORGE, S.: Energy-efficient production of clay bricks using industrial waste. Heliyon, Vol. 4, No. 10, 2018, p. e00891.

[10] ZULTINIAR, A. - FADLI, S.R. -DRASTINAWATI, Y. - THARIQ, M.R.A.: Fabrication of brick without burning process.IOP Conf. Ser. Mater. Sci. Eng., Vol. 345, No. 1, 2018.

[11] KARIYAWASAM, K.K.G.K.D.- JAYASINGHE, C.: Cement stabilized rammed earth as a sustainable construction material.Constr. Build. Mater., Vol. 105, 2016, pp. 519-527.

[12] KAKALE, A.U.: Sustainable Environment: Lateriteas Sustainable.No. 2, 2016, pp. 70-73.

[13] GALLEN, S.: SKAT Swiss Centre for Development Cooperation in Technology and Management. 1993.

[14] AKADIRI, P.O. - CHINYIO, E.A. - OLOMOLAIYE, P.O.: Design of a Sustainable Building: A Conceptual Framework for Implementing Sustainability in the Building Sector. 2012, pp. 126-152.

[15] BAYIZITLIOĞLU, B.: The Historic Environment: Policy \& Practice Conservation and Maintenance of Earth Constructions: Yesterday and Today Conservation and Maintenance of Earth Constructions: Yesterday and Today.Hist. Environ. Policy Pract., Vol. 7505, December 2017, pp. $1-32$.

[16] DEBOUCHA, S.- HASHIM, R.: Correlation between total water absorption and wet compressive strength of compressed stabilized peat bricks. Vol. 6, No. 10, 2011, pp. 2432-2438.

[17] GETACHEW, K.- MOSISA, A.: Laboratory Investigation of Locally Produced Clay Brick Quality and Suitability for Load Bearing Element in Jimma Area. Ethiopia Alemu Mosisa, Int. J. Eng. Res. Technol., Vol. 6, No. 5, 2017, pp. 809-817.

[18] IS-1077, Common Burnt Clay Building Bricks -Specification, Bur. Indian Stand., 2007.

[19] ASTM C67-90, Standard test method for the properties of fired clay bricks, Annual Book of American Society for Testing and Materials, 1996.

[20] Ethiopian Standards Agency (ESA). Solid clay bricks, ES 86:2001, Ethiopian Standard, Second edition 2001-06-27, 2011. 